\title{
Characterization of arrowroot starch in different agronomic managements ${ }^{1}$
}

\author{
Douglas Correa de Souza ${ }^{*} \mathbb{D}$, Rogério de Jesus Silva3, Thiago Sampaio Guerra², Luis Felipe Lima e Silva², \\ Luciane Vilela Resende ${ }^{2}$, Joelma Pereira ${ }^{3}$
}

10.1590/0034-737X201966050001

\begin{abstract}
Arrowroot is a plant originated in Latin America that has aroused interest in the food industry due to its high starch content, with differentiated characteristics and high commercial value. However, information on the management of arrowroot are scarce, precluding its commercial competition with other similar species, being necessary further studies with the crop. Thus, the objective of the present study was to characterize extracted starch from arrowroot grown under different agronomic management. Three agronomic factors were studied: planting systems (PS), forms of water management (WM) and planting density (PD). The experimental analyses were performed in a completely randomized design (CRD) with three replicates, being evaluated the extraction yield, percent composition, quantity of starch, $\mathrm{pH}$, titratable acidity, swelling power, solubility and electron microscopy analysis. In general, the analyzed extracted starches deriving from different agronomic treatments have low crude fiber, besides typical characteristics of arrowroot extracted starch such as texture, color, shape and size of granules, without any other apparent particle than the starch itself, indicating extraction efficiency. However, the planting density may have contributed to influence some parameters of the chemical composition of the extracted starch, such as the content of starch, ash, ether extract, protein and carbohydrate fraction.
\end{abstract}

Keywords: Maranta arundinacea L.; phytotechnical management; planting density; planting systems; unconventional vegetables; water management.

\section{INTRODUCTION}

Starch is an amylaceous produce extricated from edible parts of plants, such as tubers, roots and rhizomes. Currently, several products are found in the market using starch as raw material. In the food industry, this carbohydrate can be used to enhance texture, such as thickening agents, water retention, gelling agent and colloidal stabilizer. Several cassava and maize starch products are commonly found on the market, because their characteristics and behavior are comprehended, while starches from other unconventional sources are not as popular (Lucas et al., 2013; Andrade et al., 2017).
Arrowroot (Maranta arundinacea L.) is an example of these new sources. The species is attracting interests from the industries that produce starch in Brazil due to reports of differentiated properties of this starch in bakery products, being used as food for children, elderly or patients with intestinal disorders due to its high digestibility. Moreover, it has been a potential dietary solution for special diets, e.g., for people with celiac disease (Madhava et al., 2012; Dorta Villegas \& Pérez, 2014).

The price of the arrowroot starch in the national market has reaches values of $\mathrm{R} \$ 15.00$ to 39.00 per $\mathrm{kg}$, because of this, the cultivation of arrowroot has become a potential option in Brazilian agribusiness, especially for family

\footnotetext{
Submitted on September 24 $4^{\text {th }}, 2018$ and accepted on August 26 th 2019.

${ }^{1}$ This work is part of the first author doctoral thesis.

${ }^{2}$ Universidade Federal de Lavras, Departamento de Agricultura, Lavras, Minas Gerais, Brazil. douglascorrea@ymail.com; thiagosampaioguerra@hotmail.com; luisufla@hotmail.com; luciane.vilela@dag.ufla.br

${ }^{3}$ Universidade Federal de Lavras, Departamento de Ciência dos Alimentos, Lavras, Minas Gerais, Brazil. rogerioneto1@hotmail.com; joper@dca.ufla.br

*Corresponding author: douglascorrea@ymail.com
} 
agriculture (Moreno et al., 2017; Santos, 2019; Souza et al . 2019; Vieira et al., 2015).

However, the conservation of the species and hence studies aimed at encouraging production are fundamental, since there is no available technical information regarding the recommendations of agronomic management such as fertilization, spacing, water management, pest control, diseases and weeds and their effects on production (Souza et al., 2016) in this species. In other cultures, studies evidence that the management is directly correlated with the quality and yield of the product. For instance, cassava is considered as tolerant to drought conditions and low soil fertility, however, it shows increased productivity when irrigated under water restriction conditions (Oliveira et al., 2006), although the high water availability associated with high concentrations of nitrogen in the soil usually result in excessive shoot development and low root production (Howeler, 1982).

The result from the interaction of crop conditions (influence of soil, climate, pests, crop and cultivar management) and the influence of harvesting, drying and storage operations are factors that directly influence the industrial use to be given to the product. In face to shortage of scientific results to subsidize the cultivation of this species, the objective of the present study was to characterize starch from arrowroot grown under different agronomic management.

\section{MATERIAL AND METHODS}

\section{Design of the experiment}

The experiment was performed between October 2014 and August 2015, in Lavras, Minas Gerais, Brazil, located at $21^{\circ} 14^{\prime} \mathrm{S}, 45^{\circ} 00^{\prime} \mathrm{W}$ and $919 \mathrm{~m}$ altitude. The climate of the municipality is Cwa type, according to the climate classification of Köppen. The average annual temperature is around $19^{\circ} \mathrm{C}$, with the warmest month and the coldest month average temperatures of 22 and $16^{\circ} \mathrm{C}$, respectively (Álvares et al., 2013).

Three factors for the agronomic management of arrowroot were studied: planting systems (PS), forms of water management (WM) and planting density (PD). Each factor contained two specific categories (PS: rhizomes planted directly in the field and seedlings formed in polyethylene bags, screened and later taken to the field; WM: irrigated and dry farming; and PD: 31,250 and 50,000 plants ha $\left.{ }^{-1}\right)$. Therefore, eight treatments in the $2 \times 2 \times 2$ factorial design, in the field each plot had 18 plants being used the four central plants.

The experiment was conducted in raised beds with dimensions of $0.25 \mathrm{~m}$ high $\times 1.25 \mathrm{~m}$ wide. The soil was prepared by plowing and two harrowing in the conventional system. Based on the soil analysis data, acidity was corrected with $0.24 \mathrm{t} \mathrm{ha}^{-1}$ limestone. The fertilizers were made with ammonium sulfate, single superphosphate and potassium chloride following the recommendations of $\mathrm{Ri}$ beiro et al. (1999), adapted for tuberous. The amounts of fertilizers varied according to plant density ha ${ }^{-1}$.

In the plantation, arrowroot rhizomes of the cultivar seta were used, derived from the Germplasm Collection of Non-Conventional Vegetables of the Federal University of Lavras. Rhizomes were cross-cut about 30 to $60 \mathrm{~g}$, with at least three meristems, to generate each plant.

Both the seedlings formed in bags and the rhizomes planted directly in the field were planted in October. The seedlings were cultivated in polyethylene bags $\left(5,292 \mathrm{~cm}^{3}\right)$ filled with $60 \%$ Rohrbacher ${ }^{\circledR}$ substrate, $30 \%$ sieved soil and $10 \%$ sand, and kept in a greenhouse until transplanting after 70 days of planting, when they had four definite leaves. During this period all materials were irrigated to keep the soil always moist during the sprouting phase until the plants reach around $20 \mathrm{~cm}$ (Zárate \& Vieira, 2005).

Two levels of planting density were used, corresponding to the spacing of $40 \mathrm{~cm}$ between rows and $80 \mathrm{~cm}$ between plants, about three plants $\mathrm{m}^{-2}$ and the spacing of $40 \mathrm{~cm} \times 50 \mathrm{~cm}$, resulting in five plants $\mathrm{m}^{-2}$, with part of the experiment irrigated by drip and part without irrigation. An irrigation system was used with lateral lines composed of $16 \mathrm{~mm}$ NAAN PC drip tubes, with emitters spaced $30 \mathrm{~cm}$ and flow of $1.6 \mathrm{~L} \mathrm{~h}^{-1}$, allowing the wet surface forming a continuous band along the planting line. Irrigation management was performed at intervals of two days with an average depth of $7 \mathrm{~mm}$, depending on the rainfall, being suspended 60 days before harvest, aiming at the best quality of rhizomes.

Harvest was performed at 309 days after planting, when the shoot of plants gave more than $60 \%$ leaf senescence. After harvest, the arrowroot rhizomes were sanitized in running water and sent to the UFLA Food Science laboratory for starch extraction. Then the rhizomes were sliced into $0.5 \mathrm{~cm}$ pieces. In the laboratory, the analyses were conducted in a completely randomized design (CRD) with three replicates.

\section{Starch extraction and yield}

For starch extraction, the rhizomes were milled with distilled water, 1: 1 ratio, in an industrial blender (Lucre, model C4, Brazil), and then filtered through a fine mesh screen. The suspension was put to stand ( \pm 16 hours) in BOD incubator $\left( \pm 5^{\circ} \mathrm{C}\right)$. Then, the supernatant was removed and the precipitated starch resuspended with distilled water to be again removed. The suspension and decantation process of starch was repeated until the product presented characteristics of starch, with fine texture and white color. The samples were then pre-dried in a kiln at $45^{\circ} \mathrm{C}$ for 24 hours (to avoid gelatinization of 
granules) and cooled to room temperature (Daiuto \& Cereda, 2003). Then the samples were crushed in a blender and were stored in a flask until further use. The starch yield was determined according to Equation 1.

$\begin{aligned} & \text { Yield of } \\ & \text { starch }(\%)\end{aligned}=\frac{\text { Weight of extracted starch }(g) \times 100}{\text { Weight of rhizome used in processing }(g)}$

\section{Amount of pure starch}

The amount of pure starch was identified by washing the samples of starch by means of sugar removal, autoclaving, neutralization, deproteinization and measurement by spectrophotometer reading at $510 \mathrm{~nm}$ (Instituto Adolfo Lutz, 2008). The results were expressed in $g$ $100 \mathrm{~g}^{-1}$.

\section{Percent composition}

To characterize the starch, the analyses were performed followed the recommendations of Official Methods of Analysis of Association of Official Analytical Chemists AOAC (2019). The moisture was obtained by gravimetric method, placing the samples in a forced air circulation oven at $65^{\circ} \mathrm{C}$ until constant mass. The ether extract was used as diethyl ether as a solvent in the Soxhlet apparatus. The ash was obtained by placing the samples in the muffle at $550{ }^{\circ} \mathrm{C}$. The Kjeldahl method determined the protein content (multiplied by the factor 6.25). The fiber obtained by the gravimetric method after acid digestion and the carbohydrate fraction determined by the difference of the sum of the other elements of the centesimal composition, according to Equation 2.

$C H F=100-(M+E E+P+C F+A)$

Where: CHF: carbohydrate fraction; M: moisture; EE: ether extract; $\mathrm{P}$ : protein; $\mathrm{CF}$ : crude fiber and $\mathrm{A}$ : ash.

\section{pH and titratable acidity}

The $\mathrm{pH}$ was determined by $\mathrm{pHmeter}$ (model PHS-3E), and the filtrate was titrated with $0.1 \mathrm{~N} \mathrm{NaOH}$ to determine the titratable acidity according to the methodology described by the Instituto Adolfo Lutz (2008).

\section{Swelling power (SP) and solubility $(S)$}

The swelling power and the solubility of starches were determined according to the methodology proposed by Leach et al. (1959), adapted by Matsuguma et al. (2009), being determined according to Equation 3 and 4.

$$
\begin{aligned}
& S P(g . g-1)=\frac{\text { Precipitation weight }(g) \times 100}{\text { Sample weight }(\text { Dry base })(g) \times(100-\% \text { of supernatant })} \\
& S(\%)=\frac{\text { Weight of the supernarant }(g) \times 400}{\text { Sample weight (Dry basis) }(g)}
\end{aligned}
$$

\section{Size of granules (scanning electron microscopy)}

The granule size of the arrowroot starch was determined using a scanning electron microscope (model SEM LEO 40) by the measurement scale of electronic photography. The powder samples were placed on an aluminum surface with the aid of a double-sided carbon metallic tape covered with gold through the BAL-TEC SCD 050 gold evaporator.

\section{Statistical analysis}

The results were subjected to analysis of variance, and interpreted with observations of averages and standard deviation. For the quantitative effects (swelling power and the solubility), the data were fitted to a linear regression model. The means were compared by the Scott \& Knott (1974) clustering test to evaluate the effect of treatments at $5 \%$ probability. The coefficient of variation $(\mathrm{CV})$ was used to evaluate the experimental precision, and the statistical analysis was performed using the SISVAR ${ }^{\circledR}$ software (Ferreira, 2011) and the graphics were generated by Microsoft Excel ${ }^{\circledR}$.

\section{RESULTS AND DISCUSSION}

Starches can be used in different industry segments, such as bakery products, packaging, pharmaceuticals and cosmetics, among others. Accordingly, it is essential to evaluate, besides the yield, the nutritional and industrial properties of arrowroot starches. Preliminary studies suggest these properties are influenced by the way the crop is managed in the field. For industry, starch yield and amount of pure starch are extremely important because they are directly associated with the cost of end product (Streck et al., 2014).

\section{Starch yield and amount pure starch as a function of crop management}

When analyzing the interactions, the joint effect of the water management and the planting system is observed, besides the system and planting density in the starch yield. For the amount pure of starch, there was a combined effect of the three analyzed factors (WM x PS x PD), according to Table 1.

In the unfolding of interactions, it was verified that the starch yield in the interaction WM x PS was affected with a reduction of $29.53 \%$ in the yield when the planting was performed through seedlings and irrigated, and of $25.50 \%$ in the interaction PD x PS when using seedlings and the density of 31,250 plants ha ${ }^{-1}$ compared to the other managements used (Table 2).

Thus, the treatment that shows these factors in common (produced by seedlings, irrigation and greater spacing) has the lowest yield with $6.61 \mathrm{~g}$ extracted starch per $100 \mathrm{~g}$ 
ground rhizome, being that the most efficient treatments

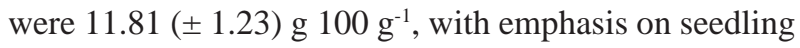
production under dry conditions at density of 50,000 plants per ha $^{-1}$ (Table 3).

In this experiment, regardless of the adopted management, the amount average of pure starch in the starch from the arrowroot, between treatments, was 85.27

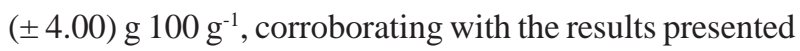

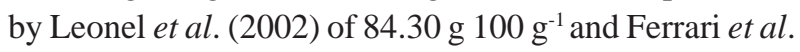

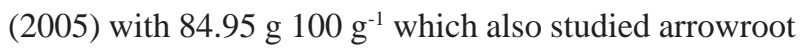
starch (Table 3). However, pure starch differed among treatments, in which the starch obtained from rhizomes produced in conditions of greater spacing, under irrigation and from rhizomes directly in the field showed the highest

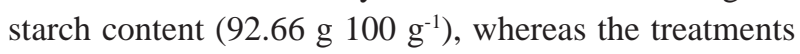
with a lower amount of pure starch showed an average of $82.24( \pm 1.97) \mathrm{g} 100 \mathrm{~g}^{-1}$ show commonly the highest planting density $(50,000$ plants ha-1).

This is probably due to the lower competition among the plants for light and hence the higher production of photoassimilates, including the starch (Taiz et al., 2017). In order to achieve significant decreases in the average starch percentages of roots, factors that strongly influence the normal development of plants are necessary, being that one of the factors is the competition with weeds or with the crop itself (Gabriel Filho et al., 2003).

\section{Percent composition}

Chemical composition of starch is presented in Table 3. It was observed that, although there was a significant difference among the moisture contents, which may be due to the accuracy of extraction method and the difference in starch characteristics, such as swelling power and distribution of granule size, all the results found in the present study [average moisture content of $3.37( \pm 0.75) \mathrm{g}$ $\left.100 \mathrm{~g}^{-1}\right]$ are well below the limits established by Brazilian legislation for commercial starches such as potatoes

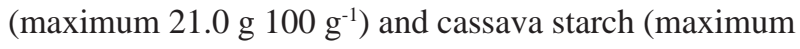

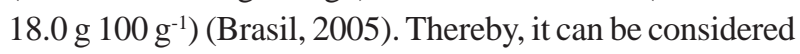
that the findings were satisfactory, since higher water contents favors the development of microorganisms, especially fungi and yeasts.

The ash contents present in the starch ranged from

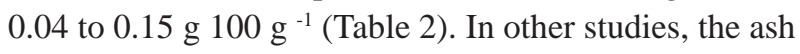

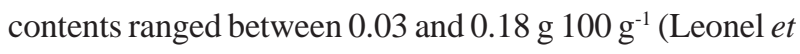
al., 2002; Ferrari et al., 2005; Cunha, 2016). The unfolding among the interactions in shows a decrease in ash content when the arrowroot was cultivated at a denser spacing regardless of the planting and irrigation system, except in the case of seedling cultivation and under dry conditions.

The ash content corresponds to the inorganic fraction of the starch, affecting the quality of the obtained starch. According to Leonel \& Cereda (2002) the lower the ash

Rev. Ceres, Viçosa, v. 66, n.5, p. 323-332, sep/oct, 2019 
content, the better the starch quality due to the greater absence of inorganic matter, which indirectly may be related to the peeling and washing stages of rhizomes. On the other hand, the ash content is related to the presence of total minerals, improving the nutritional properties of the starch.

Significant differences were observed among treatments for ether extract whose values ranged from 0.21

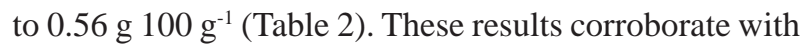
those found in the literature, in which the authors cite

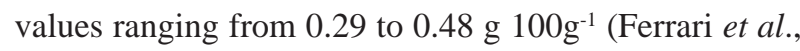
2005; Cunha, 2016). The found lipid content was low and similar to the great majority of starches from other botanical

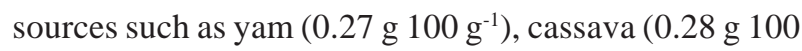

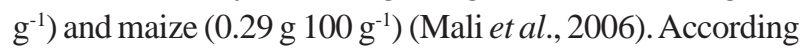
to Moorthy (2001), the lipid content can be considered

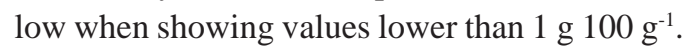

For the protein content, there was no significant difference among treatments, the average was $0.68 \mathrm{~g} 100$ $\mathrm{g}^{-1}( \pm 0.05)$, data close to the reported by Clemente Granados et al. (2014), which studied the same culture and found

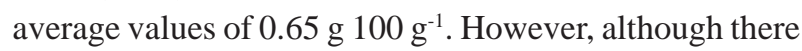
is no statistical difference it was noted that the higher planting density assures numeral value increase in content the protein in the starch (Table 2).

However, the total carbohydrates (non-nitrogenous extract) present in starches differed significantly among the treatments (Table 2), being observed lower values for treatments with higher planting density. Reinforcing such results, in the interaction between PS x WM x PD, there was a slight decrease in the carbohydrate fraction with the higher planting density.

The carrying of substances such as proteins, lipids and minerals (considered as contaminants in the product) may occur in most extraction processes of starch. These contaminants are usually present in small amounts, although they may affect the physicochemical and technological properties of the starch (Leonel \& Cereda,
2002). Thus, the purity degree of the starch is an important parameter of quality, facilitating the industrial applications. According to Rocha et al. (2008), when the sum of these constituents is lower than or equal to $1 \%$ of the total, it indicates that the starch has a high purity degree and that the extraction process was efficient.

In the present study, the sum of the results was close to $1 \%$, which may be affected by the extraction process, since the starch was purified only by decantation and not by centrifugation, perhaps guaranteeing greater purity. Except for the treatment produced by seedlings, density of 50,000 plants ha ${ }^{-1}$ and in irrigated system, presenting exactly the reference value (Figure 1).

\section{pH and acidity}

For the $\mathrm{pH}$ and titratable acidity of the starch, the treatments showed average values of $5.84( \pm 0.46)$ and 0.69 $( \pm 0.17)$, respectively, according to Table 3 . Most of native starches show pH close to neutrality (Marcon et al., 2007), whereas in the literature, the titratable acidity for arrowroot starch ranged from 0.67 to 0.80 (Leonel et al., 2002; Cunha, 2016).

Theoretically, starches from treatments produced by rhizomes directly in the field show lower acidity, conversely, the starches obtained from seedling treatment tend to be more acidic.

\section{Swelling power and solubility}

The swelling power (SP) and the solubility (S) of the starch are associated with break of chemical bonds and leaching of the native starch when heated at temperatures above the gelatinization of granules. This parameter is extremely important in several applications of these raw materials due to the great influence on the technological characteristics of end products (Matsuguma et al., 2009; Andrade et al., 2017).

The SP curves of the starch samples show continuous growth with increasing temperature, with a peak at $90^{\circ} \mathrm{C}$

Table 2: Unfolding of interactions for starch yield in the interaction in between water management and planting systems (WM x PS), and among the factors planting systems and planting density (PD x PS)

\begin{tabular}{|c|c|c|c|}
\hline & \multirow[b]{2}{*}{ Starch yield } & \multicolumn{2}{|c|}{ Planting systems } \\
\hline & & Seedling formed in bags & $\begin{array}{l}\text { Rhizomes planted directly } \\
\text { in the field }\end{array}$ \\
\hline \multirow[t]{2}{*}{ Water management } & Dry farming & $7,77 \mathrm{bB}$ & $11,42 \mathrm{aA}$ \\
\hline & Irrigation & $11,58 \mathrm{aA}$ & $10,10 \mathrm{aA}$ \\
\hline \multirow{2}{*}{ Starch yield } & & \multicolumn{2}{|c|}{ Planting density } \\
\hline & & 31,250 plants ha-1 & 50,000 plants ha ${ }^{-1}$ \\
\hline \multirow{2}{*}{ Planting systems } & Seedling formed in bags & $8,12 \mathrm{bB}$ & $11,24 \mathrm{aA}$ \\
\hline & Rhizomes planted directly in the field & $11,32 \mathrm{aA}$ & $10,19 \mathrm{aA}$ \\
\hline
\end{tabular}

The averages followed by the same lowercase letters in the columns and upper case in the lines do not differ from each other by the Scott $\&$ Knott test $(p=0.05)$. 
(Figure 2A). In general, there was no significant difference among treatments at the same temperatures; average values were $3.94 \mathrm{~g} \mathrm{~g}^{-1}( \pm 0.80)$ at $60{ }^{\circ} \mathrm{C} ; 14.42 \mathrm{~g} \mathrm{~g}^{-1}( \pm 0.79)$ at $70{ }^{\circ} \mathrm{C}$; $16.79 \mathrm{~g} \mathrm{~g}^{-1}( \pm 0.98)$ at $80^{\circ} \mathrm{C}$; and $20.52 \mathrm{~g} \mathrm{~g}^{-1}( \pm 0.98)$ at $90^{\circ} \mathrm{C}$. Therefore, the managements adopted in the experiment do not influence the SP of the arrowroot starch.

The increase in SP with increasing temperature indicates a certain influence on this water retention capacity. This fact is related to the higher vibration of molecules of the starch granule under high temperatures, causing the break of intermolecular bonds and allowing the released binding sites to perform the bonds of hydrogen with water molecule (Fennema et al., 2010).

Although the starch characteristics are affected according to the botanical source, with modifications and several other factors, the arrowroot starches obtained through the treatments showed typical behavior, being the data similar to other studies, such as the experiment by

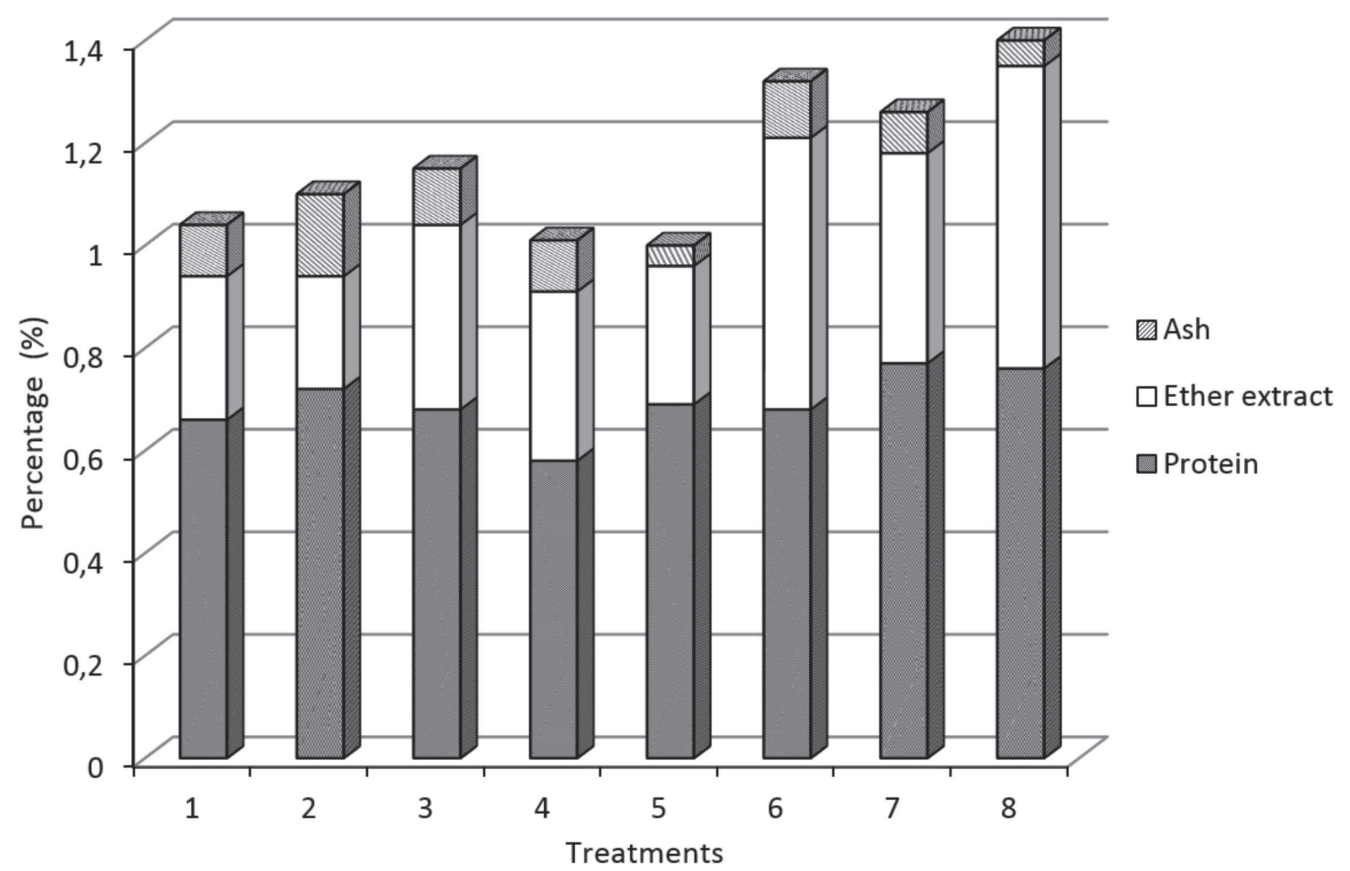

(1) Irrigation + Rhizomes $+31,250$ plants ha $^{-1}$; (2) Dry farming + Seedlings $+50,000$ plants ha ${ }^{-1}$; (3) Dry farming + Seedlings $+31,250$ plants ha ${ }^{-1}$; (4) Irrigation + Seedlings $+31,250$ plants ha $^{-1}$; (5) Irrigation + Seedlings $+50,000$ plants ha ${ }^{-1}$; (6) Dry farming + Rhizomes + 31,250 plants ha ${ }^{-1}$; (7) Dry farming + Rhizomes $+50,000$ plants ha ${ }^{-1}$; (8) Irrigation + Rhizomes $+50,000$ plants ha $^{-1}$;

Figure 1: Purity degree of the starch, by the sum of the ash content, ether extract and proteins.

Table 3: Averages of treatments for the variables of the starch chemical composition in $100 \mathrm{~g}$ of sample (g. $100 \mathrm{~g}-1)$ [dry basis]

\begin{tabular}{|c|c|c|c|c|c|c|c|c|}
\hline \multirow{4}{*}{$\begin{array}{l}\text { Chemical } \\
\text { composition } \\
\left(\mathrm{g} \mathrm{100g}^{-1}\right)\end{array}$} & \multicolumn{8}{|c|}{ Treatments } \\
\hline & \multicolumn{4}{|c|}{ Rhizomes planted directly in the field } & \multicolumn{4}{|c|}{ Seedlings formed in polyethylene bags } \\
\hline & \multicolumn{2}{|c|}{31,250 plants ha ${ }^{-1}$} & \multicolumn{2}{|c|}{50,000 plants ha ${ }^{-1}$} & \multicolumn{2}{|c|}{31,250 plants ha ${ }^{-1}$} & \multicolumn{2}{|c|}{50,000 plants ha ${ }^{-1}$} \\
\hline & Irrigation & Dry farming & Irrigation & Dry farming & Irrigation & Dry farming & Irrigation & Dry farming \\
\hline Starch yield & $11.80 \mathrm{a}$ & $10.84 \mathrm{a}$ & $11.03 \mathrm{a}$ & $9.36 \mathrm{~b}$ & $6.61 \mathrm{~b}$ & $9.63 \mathrm{~b}$ & $8.94 \mathrm{~b}$ & $13.54 \mathrm{a}$ \\
\hline QS & $92.66 \mathrm{a}$ & $87.08 \mathrm{~b}$ & $81.12 \mathrm{c}$ & $81.10 \mathrm{c}$ & $85.74 \mathrm{~b}$ & $87.70 \mathrm{~b}$ & $81.57 \mathrm{c}$ & $85.18 \mathrm{~b}$ \\
\hline Moisture & $3.94 \mathrm{f}$ & $3.39 \mathrm{~d}$ & $4.15 \mathrm{f}$ & $4.23 \mathrm{f}$ & $2.34 \mathrm{a}$ & $2.51 \mathrm{~b}$ & $2.76 \mathrm{c}$ & $3.72 \mathrm{e}$ \\
\hline Ash & $0.10 \mathrm{c}$ & $0.11 \mathrm{c}$ & $0.05 \mathrm{a}$ & $0.08 \mathrm{~b}$ & $0.10 \mathrm{c}$ & $0.11 \mathrm{c}$ & $0.04 \mathrm{a}$ & $0.16 \mathrm{~d}$ \\
\hline Ether extract & $0.28 \mathrm{~b}$ & $0.53 \mathrm{e}$ & $0.59 \mathrm{f}$ & $0.41 \mathrm{~d}$ & $0.33 \mathrm{c}$ & $0.36 \mathrm{c}$ & $0.27 \mathrm{~b}$ & $0.22 \mathrm{a}$ \\
\hline Protein & $0.66 \mathrm{a}$ & $0.68 \mathrm{a}$ & $0.76 \mathrm{a}$ & $0.77 \mathrm{a}$ & $0.58 \mathrm{a}$ & $0.68 \mathrm{a}$ & $0.69 \mathrm{a}$ & $0.72 \mathrm{a}$ \\
\hline Fiber & $0.54 \mathrm{c}$ & $0.62 \mathrm{~d}$ & $0.25 \mathrm{a}$ & $0.53 \mathrm{c}$ & $0.44 \mathrm{c}$ & $0.17 \mathrm{a}$ & $0.70 \mathrm{~d}$ & $0.36 \mathrm{~b}$ \\
\hline FG & $94.48 \mathrm{~d}$ & $94.67 \mathrm{c}$ & $94.20 \mathrm{e}$ & $93.98 \mathrm{f}$ & $96.21 \mathrm{a}$ & $96.17 \mathrm{a}$ & $95.54 \mathrm{~b}$ & $94.82 \mathrm{c}$ \\
\hline $\mathrm{pH}$ & $5.98 \mathrm{~d}$ & $6.42 \mathrm{e}$ & $6.09 \mathrm{~d}$ & $6.39 \mathrm{e}$ & $5.67 \mathrm{c}$ & $5.40 \mathrm{~d}$ & $5.65 \mathrm{c}$ & $5.10 \mathrm{e}$ \\
\hline TA & $0.65 \mathrm{~b}$ & $0.53 \mathrm{a}$ & $0.63 \mathrm{~b}$ & $0.53 \mathrm{a}$ & $0.72 \mathrm{~b}$ & $1.08 \mathrm{c}$ & $0.70 \mathrm{~b}$ & $0.65 \mathrm{~b}$ \\
\hline
\end{tabular}

QS: Quantity of starch; TA: Titratable acidity. Averages followed by the same letters in the lines do not differ from each other by the Scott $\&$ Knott test $(p=0.05)$.

Rev. Ceres, Viçosa, v. 66, n.5, p. 323-332, sep/oct, 2019 
Matsuguma et al. (2009), which characterized native and oxidation-modified arracacha starch (Arracacia xanthorrhiza) and found values close to those reported in the present study.

In the solubility $(\mathrm{S})$, the regressions show a different behavior among the samples at 60 and $70{ }^{\circ} \mathrm{C}$ (Figure 2B). The treatment performed without irrigation, in the smallest spacing and produced by seedlings shows values of $1.93 \%$ and $5.68 \%$, higher to the other treatments that show an average of $0.49 \%( \pm 0.30)$ and $1.93 \%( \pm 0.66)$, respectively, at given temperatures. However, with the increase in temperature, the behavior of treatments are similar to each other, with $5.95 \%( \pm 0.35)$ at $80^{\circ} \mathrm{C}$ and $7.48 \%( \pm 0.46)$ at $90{ }^{\circ} \mathrm{C}$.
It is noteworthy that the solubility of arrowroot starch samples was higher at $90{ }^{\circ} \mathrm{C}$, being important to highlight that a large part of granules are already gelatinized or swollen at this temperature range. According to Gomes et al. (2005), this is explained by the leaching of amylose into the medium and hence increasing the leaching of starch solutions.

\section{Scanning electron microscopy (SEM)}

The microscopic analysis of granules performed in the arrowroot starch showed that there was no difference in size and shape among the different management methods adopted. The granules show a smooth structure, without

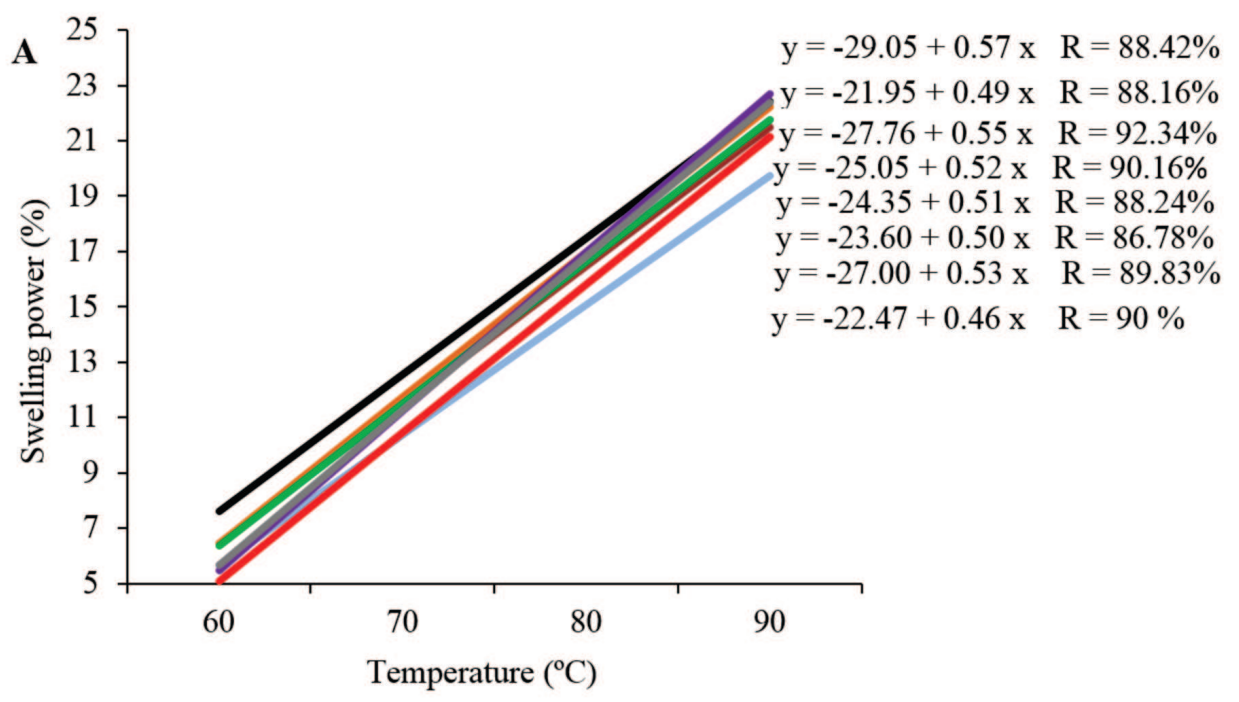

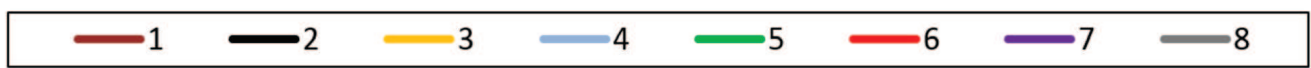

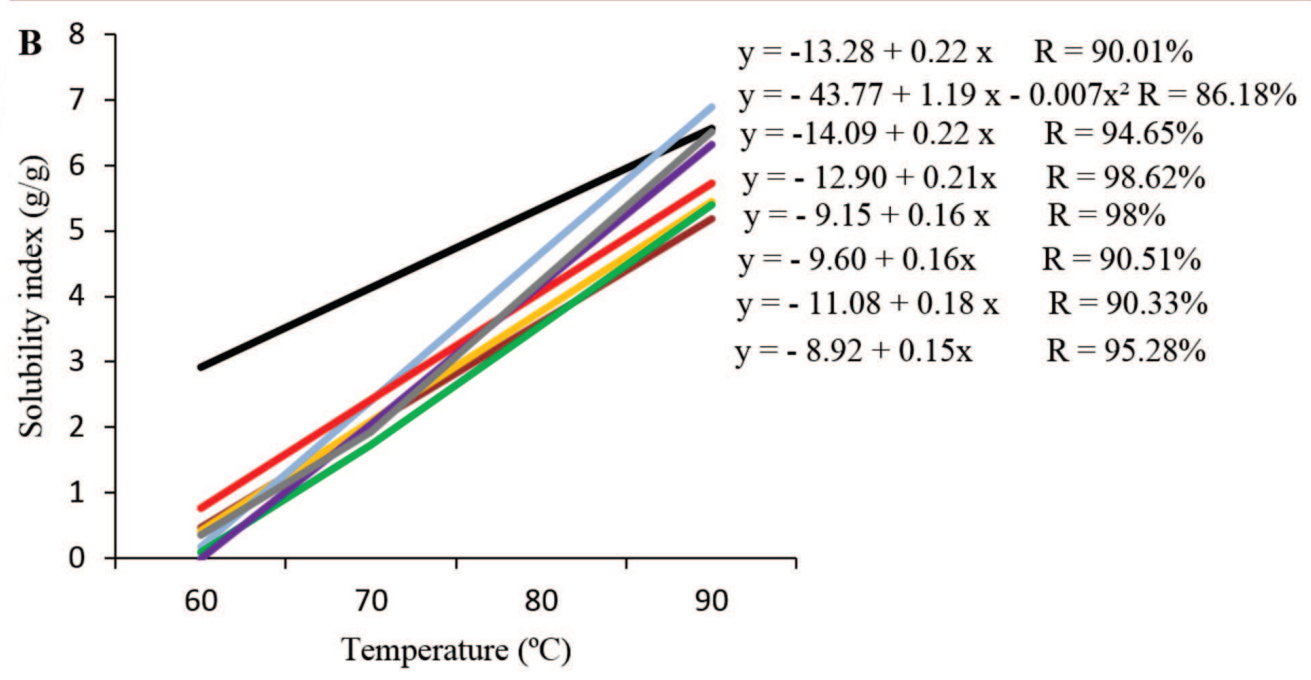

(1) Irrigation + Rhizomes $+31,250$ plants $a^{-1}$; (2) Dry farming + Seedlings $+50,000$ plants ha ${ }^{-1}$; (3) Dry farming + Seedlings $+31,250$ plants ha ${ }^{-1}$; (4) Irrigation + Seedlings $+31,250$ plants $^{a^{-1}}$; (5) Irrigation + Seedlings $+50,000$ plants ha ${ }^{-1}$; (6) Dry farming + Rhizomes + 31,250 plants ha- ${ }^{-1}$; (7) Dry farming + Rhizomes $+50,000$ plants ha- ${ }^{-1}$; (8) Irrigation + Rhizomes $+50,000$ plants ha ${ }^{-1}$;

Figure 2: Regression of (A) swelling power and (B) solubility of starch obtained from arrowroot samples collected from treatments (PS x WM x PD). 

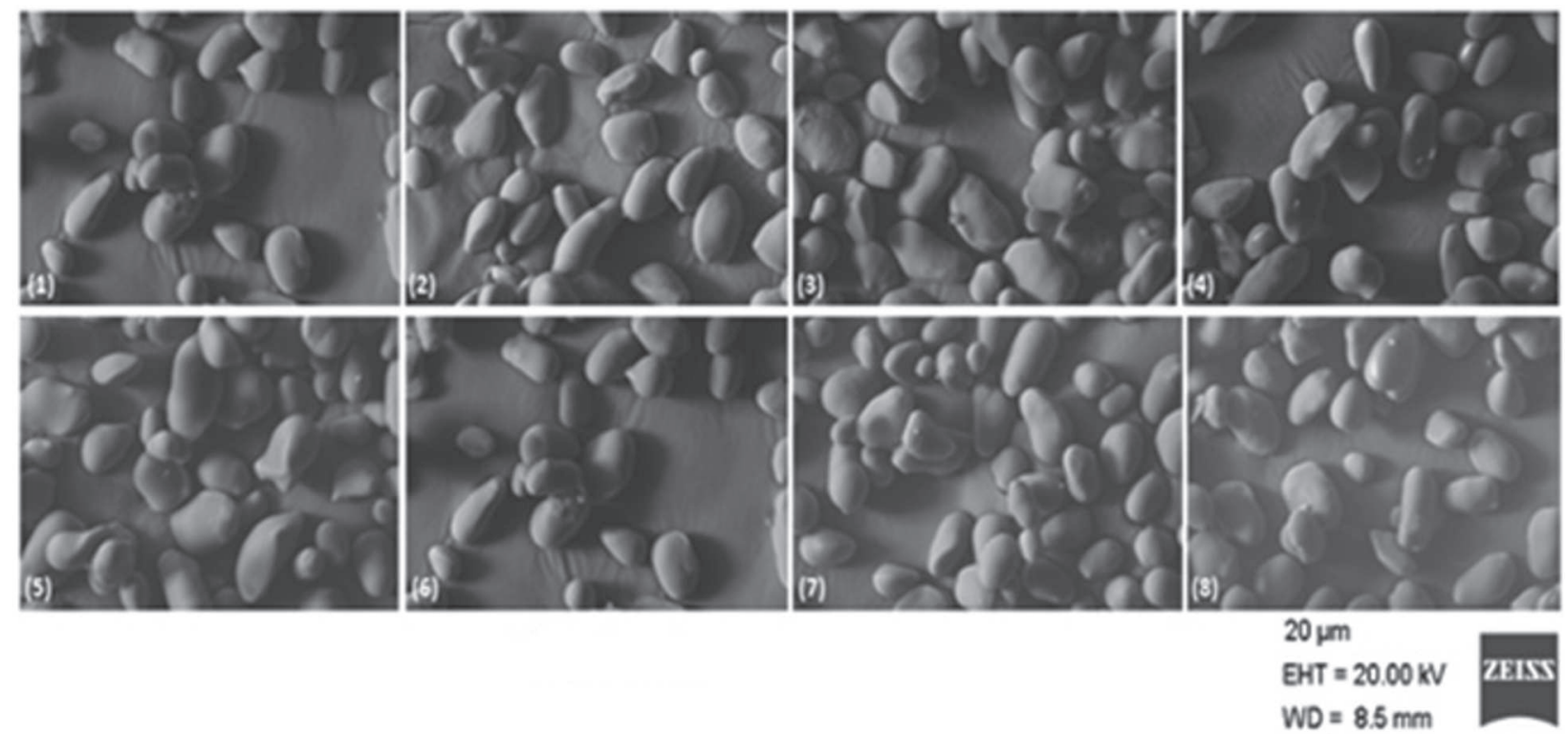

(1) Irrigation + Rhizomes $+31,250$ plants ha ${ }^{-1}$; (2) Dry farming + Seedlings $+50,000$ plants ha ${ }^{-1}$; (3) Dry farming + Seedlings $+31,250$ plants ha $^{-1}$; (4) Irrigation + Seedlings $+31,250$ plants ha $^{-1}$; (5) Irrigation + Seedlings $+50,000$ plants ha ${ }^{-1}$; (6) Dry farming + Rhizomes + 31,250 plants ha ${ }^{-1} ;(7)$ Dry farming + Rhizomes $+50,000$ plants ha $^{-1}$; (8) Irrigation + Rhizomes $+50,000$ plants ha ${ }^{-1}$;

Figure 3: SEM photomicrographs of arrowroot granules in different agronomical treatments. 600x magnification and $20 \mu \mathrm{m}$ scale.

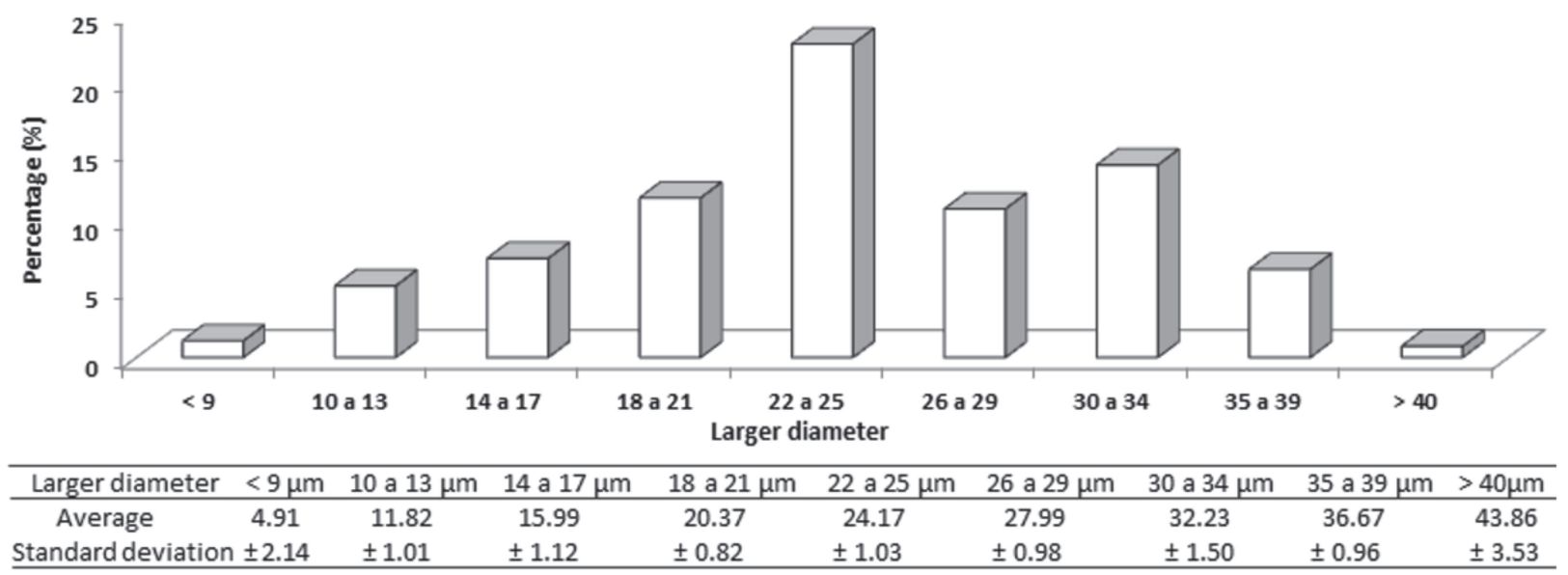

Figure 4: Size distribution (larger diameter in micrometer) of arrowroot granules in different agronomical treatments.

superficial porosity or irregularities, demonstrating intact and undamaged granules. Predominant circular and ovoid shape, according to Pérez et al. (1997) with bean shape (Figure 3).

Among the treatments, the size (larger diameter) of granules ranged from 3 to $50 \mu \mathrm{m}$, with a homogeneous distribution, predominating granules in the range from 20 to $35 \mu \mathrm{m}$ (Figure 4), similar to the range presented by Leonel (2007), from 20 to $40 \mu \mathrm{m}$. Among the treatments, the average size of granules was $24.97 \mu \mathrm{m}( \pm 7.33)$.

It is important to note that the shape and size of starch granules vary according to the species. Although the morphology is also dependent on the biochemistry of the chloroplast or amyloplast, as well as the plant physiology, and the size distribution varies with the development stage of the plant and tuber form (Singh et al., 2003; Leonel, 2007).

\section{CONCLUSION}

In general, the analyzed starches deriving from different agronomic treatments have low crude fiber, besides typical characteristics of arrowroot starch such as texture, color, shape and size of granules, without any other apparent particle than the starch itself, indicating extraction efficiency.

The agronomic management also did not influence the swelling power of the evaluated starches. However, the planting density contributed to influence some parameters 
of the chemical composition of the starch, such as the content of starch, ash, ether extract, protein and carbohydrate fraction.

\section{ACKNOWLEDGEMENTS, FINANCIAL SUPPORT AND FULL DISCLOSURE}

The authors would like to thank the funding agencies CAPES and FAPEMIG of the Brazilian government for the partial financial support for the research in this paper. We took the opportunity to inform you that there was no conflict of interest.

\section{REFERENCES}

Álvares CA, Stape JL, Sentelhas PC, Goncalves JLM \& Sparovek G (2013) Koppen's climate classification map for Brazil. Meteorologische Zeitschrift, 22:711-728.

Andrade LA, Barbosa N \& Pereira J (2017) Extraction and properties of starches from the non-traditional vegetables Yam and Taro. Polímeros, 27:151-157.

AOAC - Association of Official Analytical Chemists (2019) Official methods of analysis of the Association of Official Analytical Chemists. $21^{\text {st }}$ ed. Gaithersburg, Maryland. 3000 p.

Brasil (2005) Resolução RDC nº 263, de 22 de setembro de 2005. Aprova o Regulamento Técnico para produtos de cereais, amidos, farinhas e farelos. DOU, 23/09/2005, seção 1, p.368-369.

Cunha AL (2016) Caracterização do amido da araruta tipos seta e redonda, visando utilização na indústria de alimentos. Dissertação de Mestrado. Universidade Federal de Lavras, Lavras. 112p.

Clemente Granados C, Guzman CLE, Acevedo CD, Díaz MM \& Herrera AA (2014) Propiedades funcionales del almidon de sagu (Maranta arundinacea). Biotecnología en el Sector Agropecuario y Agroindustrial, 12:90-96.

Daiuto ER \& Cereda MP (2003) Amido como suporte na desidratação por atomização e em microencapsulamento. In: Cereda MP \& Vilpoux OF (Eds.) Tecnologia, usos e potencialidades de tuberosas amiláceas sul americanas. São Paulo, Fundação Cargill. p. 449-475.

Dorta Villegas AM \& Pérez ATC (2014) Determinación del contenido de hierro, fósforo, calcio y algunos factores antinutricionales en harina del rizoma de guapo (Maranta arundinacea). Saber, 26:146-152.

Fennema OR, Damodaran S \& Parkin KL (2010) Química de Alimentos de Fennema. $4^{\circ}$ ed. Porto Alegre, Artmed. 900p.

Ferrari TB, Leonel M \& Sarmento SBS (2005) Características dos rizomas e do amido de araruta (Maranta arundinacea) em diferentes estádios de desenvolvimento da planta. Brazilian Journal of Food Technology, 8:93-98.

Ferreira DF (2011) Sisvar: a computer statistical analysis system. Ciência e Agrotecnologia, 35:1039-1042.

Gabriel Filho AG, Strohhaecker L \& Fey E (2003) Profundidade e espaçamento da mandioca no plantio direto na palha. Ciência Rural, 33:461-467

Gomes AMM, Silva CEM \& Ricardo NMPS (2005) Effects of annealing on the physicochemical properties of fermented cassava starch (polvilho azedo). Carbohydrate Polymers, 60:01-06.

Howeler RH (1982) Nutricion mineral e fertilizacion de la yuca. In: Domingues CE (Ed.) Yuca: investigacion, producion y utilizacion. Cali, PNUD. p.317-357.
Instituto Adolfo Lutz (2008) Métodos físico-químicos para análise de alimentos. São Paulo, Instituto Adolfo Lutz. 1020p.

Leach HW, McCowen LD \& Schoch TJ (1959) Structure of the Starch Granule. I. Swelling and Solubility Patterns of Various Starches. Cereal Chemistry, 36:534-544.

Leonel M \& Cereda MP (2002) Caracterização físico-química de algumas tuberosas amiláceas. Ciência e Tecnologia de Alimentos, 22:65-69.

Leonel M, Sarmento SBS \& Cereda MP (2002) Processamento da araruta (Maranta arundinacea) para extração e caracterização da fração amilácea. Brazilian Journal of Food Technology, 93:151-155

Leonel M (2007) Análise da forma e tamanho de grânulos de amidos de diferentes fontes botânicas. Ciência e Tecnologia de Alimentos, 27:579-588.

Lucas JA, Castaño VDQ \& Valencia CAC (2013) Caracterización de harina y almidón obtenidos a partir de plátano guineo AAAea (Musa sapientum L.). Acta Agronómica, 62:83-96.

Madhava NM, Sheema F, Ragu SS, Ramasamy R \& Manisha G (2012) Morphological, structural, and functional properties of maranta (Maranta arundinacea L) starch. Food Science and Biotechnology, 21:747-752.

Mali S, Grossmann MVE, García MA, Martino MN \& Zaritzky NE (2006) Effects of controlled storage on thermal, mechanical and barrier properties of plasticized fillms from different starch sources. Journal of Food Engineering, 75:453-460.

Marcon MJA, Avancini SRP \& Amante ER (2007) Propriedades químicas e tecnológicas do amido de mandioca e do polvilho azedo. Florianópolis, UFSC. 101p.

Matsuguma LS, Lacerda LG, Schnitzler E, Filho MASC, Franco CML \& Demiate IM (2009) Characterization of native and oxidized starches of two varieties of Peruvian carrot (Arracacia xanthorrhiza, b.) from two production areas of Paraná state, Brazil. Brazilian Archives of Biology and Technology, 52:701713.

Moorthy SN (2001) Tuber crop starches. $2^{\text {nd }}$ ed. Thiruvananthapuram, Central Tuber Crops Research Institute. $52 \mathrm{p}$.

Moreno LB, Torales EP, Heid DM, Zárate NAH \& Abrão MS (2017) Influence of plant density and hilling on yield and profitability of arrowroot. Pesquisa Agropecuária Tropical, $47: 465-471$

Oliveira SL, Coelho EF \& Nogueira CCP (2006) Irrigação. In Souza LS, Farias AR, Mattos PLP \& Fukuda WMG (Ed.) Aspectos socioeconómicos e agronómicos da mandioca. Cruz das Almas, Embrapa Mandioca e Fruticultura Tropical. p. 291-300.

Pérez E, Lares M \& González Z (1997) Some characteristics of sagu (Canna edulis) and zulu (Maranta sp) rhizomes. Journal of Agricultural and Food Chemistry, 45:2546-2549.

Ribeiro AC, Guimarães PTG \& Alvarez V VH (1999) Recomendações para o uso de corretivos e fertilizantes em Minas Gerais: $5^{\circ}$ Aproximação. Viçosa, Comissão de fertilidade do solo do estado de Minas Gerais. 322p.

Rocha TS, Demiate IM \& Franco CML (2008) Características estruturais e físico-químicas de amidos de mandioquinha salsa (Arracacia xanthorrhiza). Ciência e Tecnologia de Alimentos, $23: 620-628$

Santos EF (2019) Araruta da Bahia. Available at: <https:// ararutadabahia.loja2.com.br/308427-Araruta-Pacote-de-1Kg>. Accessed on July $02^{\text {nd }}, 2019$.

Scott A \& Knott M (1974) Cluster-analysis method for grouping means in analysis of variance. Biometrics, 30:507-512. 
Singh N, Singh J, Kaur L, Sodhi NS \& Gill BS (2003) Morphological, thermal and reological properties of starches from different botanical sources. Food Chemistry, 81:219-231.

Souza DC, Costa PA, Silva LFLS, Guerra TS, Resende LV \& Pereira J (2019) Productivity of rhizomes and starch quantification in cultures of different vegetative propagules of arrowroot. Journal of Agricultural Science, 11:419-425.

Souza DC, Silva LFL, Resende LV, Costa PA, Guerra TS, Gonçalves WM \& Pereira TAR (2016) Conservação pós-colheita de araruta em função da temperatura de armazenamento. Magistra, 28:403-410.

Streck NA, Pinheiro DG, Zanon AJ, Gabriel LF, Rocha TSM, Souza AT \& Silva MR (2014) Efeito do espaçamento de plantio no crescimento, desenvolvimento e produtividade da mandioca em ambiente subtropical. Bragantia, 73:407-415.
Taiz L, Zeiger E, Møller IM \& Murphy A (2017) Fisiologia e Desenvolvimento Vegetal. $6^{\mathrm{a}}$ ed. São Paulo, Artmed. 888 p.

Vieira JCB, Colombo JN, Puiatti M, Cecon PR \& Silvestre HC (2015) Desempenho da araruta 'Viçosa' consorciada com crotalária. Agrária, 10:518-524.

Zárate NAH \& Vieira MC (2005) Produção da araruta "comum" proveniente de três tipos de propágulos. Ciência e Agrotecnologia, 29:995-1000. 